\title{
Digital Financial Services Market Development: Background and Prospects
}

\author{
M.P. Loginov, N.V.Usova*, E.E. Nedorostkova \\ The Russian Presidential Academy of National Economy and Public Administration, Ekaterinburg, Russia \\ *Corresponding author. Email: nata-ekb-777@yandex.ru
}

\begin{abstract}
Subject. In the context of economy digitalization, the development of digital financial services market is an objective consequence of the economic relations development. In this regard, the significant potential of the digital financial services should be used to improve the financial architecture and the quality of life through developing the digital financial services for both legal entities and the population. The aim of the research is to identify the background and develop the perspective directions for advancing the digital financial services under digital transformation of economy both at national and international levels. Methodology. Using analysis and comparison, the research featuresthe dynamics of population change andonline population in Russia compared to global trends, as well as the current state of internet demand. In the authors' view, the digital financial services development is based on a cybernetic approach, which providesa certain synergistic effect. Results. Original approaches to the "digital financial market" and "potential of digital financial services market" categories areproposed and the mechanism for managing the development of the digital financial services market is also developed. Conclusions are made that the digital financial services market is one of the key elements of the national economy, which aims at solving problems connected with financial services accessibility for the population. Like any element of the economy, the market for digital financial services has certain advantages and disadvantages, but they do not have a significant negative impact on the financial system as a whole and the financial services market in particular.
\end{abstract}

Keywords: digital financial market, online population, market subsegment, digital financial services

\section{INTRODUCTION}

The evolution of global economy and scientific and technological progress, significantly changing both types and essential characteristics of services provided, require urgent digitalization of national economy, which will increase the level of not only national competitiveness in the international market, but also quality of life, as well as economic growth rate.

Currently, the digital services development is quite a challenge for the national economy, and the need for a clear and detailed improvement of the Russian economy is a priority development trend.

According to the HSE, only $49 \%$ of companies had their official website in 2018, which is considerably lower than that in countries like Finland (96\%), Sweden (92\%), Japan (90\%) and Germany (87\%). [7]

Moreover, for these companies, the most in-demand online activities are using e-mail (86.4\%), searching for information $(85.6 \%)$ and financial transactions, including bank ones $(66.7 \%)$.

The dynamics of the population change and the number of internet-users in Russia in comparison with global trends are of specific interest (table 1).

Table 1 Dynamics of population change and online population[compiled based on 1,2]

\begin{tabular}{|c|c|c|c|c|}
\hline \multirow[t]{2}{*}{ Indicator } & \multicolumn{2}{|c|}{ World } & \multicolumn{2}{|c|}{$\mathrm{RF}$} \\
\hline & January 2019 & $\begin{array}{l}\Delta \quad \text { Jan.2019 to } \\
\text { Jan.2018 }\end{array}$ & January 2019 & $\begin{array}{l}\Delta \operatorname{Jan} .2019 \quad \text { to } \\
\text { Jan.2018 }\end{array}$ \\
\hline $\begin{array}{l}\text { General } \\
\text { population }\end{array}$ & $\begin{array}{l}7,676 \text { bn people } \\
\text { (urbanization } 56 \% \text { ) }\end{array}$ & $\begin{array}{l}+1,1 \% \\
(+84 \text { mln people })\end{array}$ & $\begin{array}{l}143,9 \text { mln people } \\
\text { (urbanization } 75 \% \text { ) }\end{array}$ & $\begin{array}{l}(-0,03 \%) \\
(-47 \quad \text { thousand } \\
\text { people })\end{array}$ \\
\hline $\begin{array}{l}\text { Online } \\
\text { population }\end{array}$ & $\begin{array}{l}4,388 \text { bn } \\
\text { (adoption 57\%) }\end{array}$ & $\begin{array}{l}+9,1 \% \\
(+367 \mathrm{mln})\end{array}$ & $\begin{array}{l}109,6 \text { mln } \\
\text { (adoption 76\%) }\end{array}$ & $\begin{array}{l}(-0,4) \% \\
(-459 \text { thousand })\end{array}$ \\
\hline
\end{tabular}


As of January 2019, the total number of mobile connections was 248.2 million, which makes $172 \%$ of the $\mathrm{RF}$ total population. Therefore, the implication can be that certain users have several connections and internet access points.

In its turn, the importance and relevance of internet services in general and digital financial service in particular is confirmed by the following facts.

First, $76 \%$ of users have an account with certain financial institution and $40 \%$ buy or pay online, justifying the demand for both mobile and internet banking.

Second, $81 \%$ of users search the internet for goods or services for further buying them, $82 \%$ of users visit online stores (without differentiation by access device), $44 \%$ made a purchase using a laptop / desktop computer and $32 \%$ - a mobile device.

Of practical interest are also the following 2018 data featured in the "Digital Economy: 2020" digest: [7]

- $77 \%$ of total households in Russia have internet access.

- $65 \%$ of the RF adult population use mobile phones (smartphones) to access the internet outside home or work.

- In Italy and Japan this makes only $39 \%$ and in the Republic of Korea - 96\%.

- More than a third of Russians (35\%) order goods and services online.

- Quite a lot of the Russian internet users (39\%) make online financial transactions.

All of the above data is the indication of digitalization of the economy and of every field of human life.

\section{BACKGROUND}

Rapid growth and globalization of economic processes affect every field, including national financial market.

"Guidelines for the RF financial market development in 2019 - 2021"[3] define financial market as a system of economic and legal relations connected with the use of money as means of accumulation and payment, financial tools circulation and as social and business environment where financial market participants operate.

Digitalization of technological processes is the priority direction of the financial organizations competitiveness increase. The digitalization process of the Russian economy was launched in 2017 when the "Strategy for information society development in the Russian Federation in 2017-2030" [6] and the "Digital economy of the Russian Federation" program [5] were adopted.

In the authors' view, digital financial market is a subsegment of financial market consisting of specialized financial institutions, with digital financial instruments, electronic money and digital financial services being the subject of their relations.

Digital financial services in the narrow sense are services in relation to digital financial assets, electronic money, and in the broad sense, these are financial market services through internet, mobile applications, etc. The digital financial services include information, communication, cybersecurity, service, financial products servicing and others.
The potential of digital financial services market is perceived as a combination of priority directions for the financial market sub-segment development under external and internal environment factors considering the interaction specifics of its key participants and particular qualitative and quantitative features of objects of financial digital services market.

At the present stage of development, the key competitive factors in the service sector are lead time and convenience. It is the digital transformation of financial services, which can provide a comprehensive approach to these two factors.

The first is that although received in tangible form digital services can be provided at the time convenient for the client.

Second, the result of digital financial services can be visualized and individualized, which is extremely important for the service sector.

Third, digitalization erases boundaries of services provision, which in its turn reduces entrepreneurial risks in the sector.

The main reasons of the digital financial market development are the following.

Firstly, two processes are the general trends of global economy development, globalization on the one hand and integrative economic processes on the other.

Secondly, crisis phenomena around the world and a high polarization degree of financial market.

Thirdly, consumer factor influence, the more sophisticated financial needs in particular, which stimulates the increasing level of innovative activity of financial organizations.

In addition, most digital financial services have a transnational dimension.

Notably, the following global trends indicate a great potential for the further share growth of digital financial services [4]:

- by 2020, 35 - 50\% of bank customers will be mobile bank users;

- $82 \%$ of financial institutions expect an increase in the number of partnerships with fin-tech companies in the next 3-5 years;

- 56\% of financial institutions included digital transformation in their business strategy;

- $\$ 24.7$ billion ( $\$ 11.6$ billion in the first half of 2017) was invested in fin-tech companies in 2016, which istwo times as high as in 2013, indicating a high growth rate of fin-tech industry.

At the end of 2016, the Russian Federation ranked $41^{\text {st }}$ in digital readiness of economy significantly lagging behind the ten top countries, such as Singapore, Finland, Sweden, Norway, the US, the Netherlands, Switzerland, Great Britain, Luxembourg and Japan. In terms of economic and innovative results of using digital technologies, the Russian Federation ranked $38^{\text {th }}$,far behind the leading countries, like Finland, Switzerland, Sweden, Israel, Singapore, the Netherlands, the US, Norway, Luxembourg and Germany .[5] 
Essential is the development framework of digital financial services market, i.e. a toolkit to control the combination of financial market participants' economic relations regarding production, distribution, exchange and consumption of goods provided in intangible form.

The evolving digital financial services market is based on a cybernetic approach, and the reasons are the following.

First, it allows for building direct and feedback communication in management process.

Second, breaking the entire system under control into separate subsystems with subsequent supervision.
Third, the ability to track environmental indicators and correlate them with regulatory standards.

Next, the permanent process of collecting, transmitting and converting information about the object under control.

All this provide fora certain synergistic effect from the evolving digital financial services market.

Firstly, reducing costs (time, organizational, financial) of organization, provision and receiving of services.

Secondly, reducing administrative barriers and increasing the service delivery transparency.

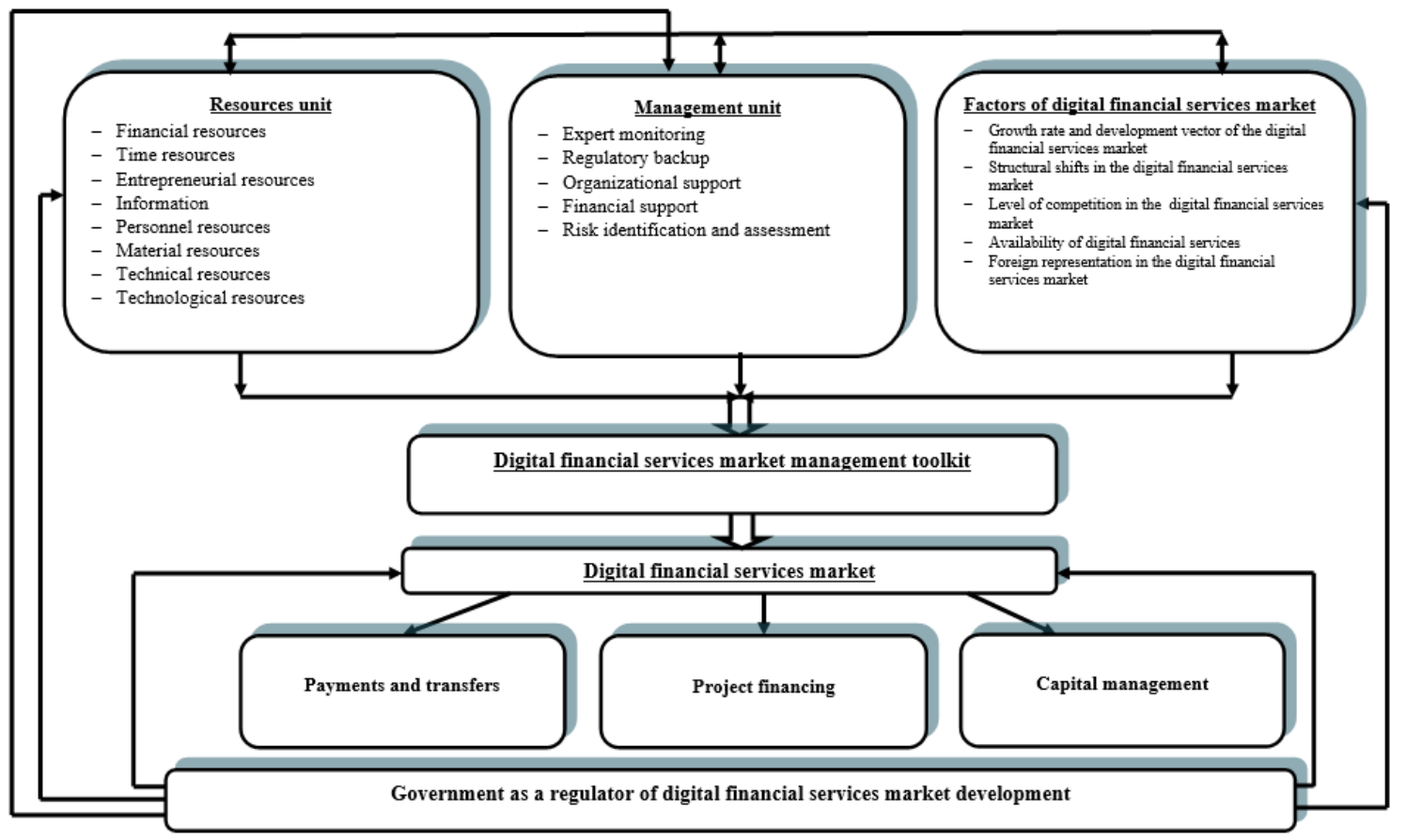

Figure 1 Framework of digital financial services market development management (compiled by authors)

Figure 1 shows mechanism of managing the development of the financial services market:

- Resource unit is a set of resources used in the process of managing the development of the digital financial services market, including financial, time, material, entrepreneurial, human, technical and technological, as well as information generated both in the process of management activities initiating and monitoring in the process of digital financial services market management.

- Management unit is a set of management actions aimed at digital financial services market development. It includes methodological, regulatory, organizational, financial support and also identification and assessment of risks in the digital financial services market.

- Factors of digital services market are a set of indicators characterizing the current state and development trends of the digital financial services market, including growth rate and development vector of digital services market, competition level and structural shifts, accessibility of digital financial services and presence of foreign providers in digital financial services market.

- Toolkit for managing digital financial services market (methods, algorithms, activities, projects, programs, project portfolios, technologies, roadmaps, development strategies).

In terms of the main product, which is provided, the following segments of the digital financial market are identified; payment, savings, credit, investment, insurance and pension.

The introduction and development of digital financial services is targeted at solving such problems as:

- innovation and investment activity increase in the national economy;

- geographical expansion of market participants in the regions through automatization and standardization;

- use of personalized promotion tools;

- demand forecasting; 
- integrationof manufacturer and consumer into the single real time digital space to provide services and coordinate activities;

- small and medium business development in the service sector;

- quality of life and services availability improvement for all social groups.

Considering the market of digital financial services, certain advantages and disadvantages can be revealed.

The advantages of the digital financial services market are:

- operational costs cutting

- low entrybarriers for all the participants

- market self-regulation based on supply and demand

- information technology consolidation by financial organizations for businessdiversification,

- information asymmetry reduction;

- pricing efficiency improvement;

- expansion of the range of financial services and clients. The disadvantages include weak legislative framework of both taxation issues and market functioning, as well as low development level of digital financial services market infrastructure.

The implementation of the main trends of financial technologies in 2018-2020 [4] will contribute to innovative technologies development in financial market of the Russian Federation and the Bank of Russia, which will increase financial products and services availability, both for private and corporate sectors together with the RF financial sector competitiveness.

Digital transformation has become one of the innovative development trends in financial market.

In the field of financial market development, the Bank of Russia has set the following goals by 2021 [4]:

topromote competition in the financial market;

toincrease availability, quality and range of financial services;

toreduce risks and costs in financial sector;

toincrease competitiveness of Russian technologies.

Moreover, goals achievement is based on the following tasks:

- (RegTech, SupTech, Big Data and Smart Data, mobile and cloud technologies, etc.) in the field of legal regulation and digitization in the financial market;

- transition to electronic interaction of market participants, including Bank of Russia and other market actors;

- staff development in the field of financial technologies by means of ongoing studyingmodern financial tools;

- increasing the level of technological safety and sustainability of using financial technologies, and operational interaction with financial market participants for prompt response and cyber attacksprevention;

- interaction in the frames of the Eurasian Economic Union for technological standards harmonization and unification and a single payment space development, using new financial technologies;

- creation of a regulatory platform for the Bank of Russia, assisting in the innovative financial technologies
- national economy efficiency and competitiveness improvement;

and services development, as well as time and other implementation costs minimization.

\section{CONCLUSION}

Achievement of the set goals will give theopportunity, on the one hand, to increase the level of competition in financial market, and on the other hand, to change the quantitative and qualitative characteristics of the range of financial services, which in turn will lead to minimization of risks associated with the use of internet as a platform of market participants' interaction and reduction of population distrust in innovative digital financial products. In addition, the development of digital financial services market will contribute to solving a number of problems of financial services availability, in particular, bridging the gaps of regional economic development andincreasing the level of trust in financial instruments and financial literacy of the population, which is of great significance for small towns and rural areas.

\section{REFERENCES}

[1] Digital 2019: global internet use accelerates [electronic resource]// We are social URL:

https://wearesocial.com/blog/2019/01/digital-2019-globalinternet-use-accelerates (reference date: 03.01.2020)

[2] Digital trends in Russia 2019 [electronicresource]// ICT.Moscow URL: https://ict.moscow/research/didzhitaltrendy-v-rossii-2019/ (reference date: 03.01.2020)

[3] Main development directions of the RF financial market for the period of 2019 - 2021 [electronicresource] // The Central Bank of theRF. URL:

https://www.cbr.ru/content/document/file/71220/main_dir ections.pdf (reference date: 27.07.2019)

[4] Main trends of the financial technologies development in 2018-2020 [electronicresource] // The Central Bank of theRF. URL:

https://www.cbr.ru/statichtml/file/36231/on_fintex_2017. pdf (reference date:27.07.2019)

[5] Resolution of the RF Government of 28.07.2017 N 1632-r "On approval of the "Digital Economy of the Russian Federation" program"[electronicresource] // Access from ref.-legal system "Consultant Plus"

[6] Decree of the President of the Russian Federation of 09.05.2017 N 203 "On the Strategy for the Information Society Development in the Russian Federation for 2017 2030" [electronic resource] // Access from ref.-legal system "Consultant Plus"

[7] Digital economy: 2020 [electronic resource]// ICT.Moscow

URL: https://ict.moscow/research/tsifrovaia-ekonomika2020/ (reference date: 02.01.2020) 